Summer 2011

\title{
Utopian Justice: A Review of Global Justice, A Cosmopolitan Account, by Gillian Brock
}

Katelyn Miner

Indiana University Maurer School of Law, kmminer@indiana.edu

Follow this and additional works at: https://www.repository.law.indiana.edu/ijgls

Part of the International Law Commons

\section{Recommended Citation}

Miner, Katelyn (2011) "Utopian Justice: A Review of Global Justice, A Cosmopolitan Account, by Gillian Brock," Indiana Journal of Global Legal Studies: Vol. 18 : Iss. 2 , Article 12.

Available at: https://www.repository.law.indiana.edu/ijgls/vol18/iss2/12

This Book Review is brought to you for free and open access by the Law School Journals at Digital Repository @ Maurer Law. It has been accepted for inclusion in Indiana Journal of Global Legal Studies by an authorized editor of Digital Repository @ Maurer Law. For more information, please contact rvaughan@indiana.edu.

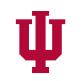

JEROME HALL LAW LIBRARY

$$
\text { INDIANA UNIVERSITY }
$$

Maurer School of Law
Blooming ton 


\title{
Utopian Justice: A Review of Global Justice, A Cosmopolitan Account by Gillian Brock
}

\author{
KATELYN MINER*
}

In Global Justice, A Cosmopolitan Account, Gillian Brock, an associate professor of philosophy at the University of Auckland in New Zealand, posits a compelling argument in favor of global justice. Through her theoretical framework and practical examples, Brock asserts that she has "develop[ed] a viable cosmopolitan model of global justice that takes seriously the equal moral worth of persons, yet leaves scope for a defensible form of nationalism along with other legitimate

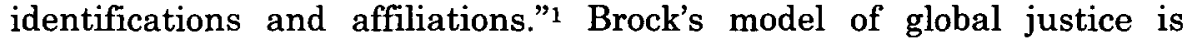
grounded in moral cosmopolitan theory. ${ }^{2}$ She argues that as the world's societies and cultures become more intertwined, typically through the process of globalization, people must understand that each individual is a "member of a global community of human beings" and, as such, individuals owe certain obligations to all other members, even those distant to them. ${ }^{3}$ According to Brock, moral cosmopolitanism breaks down the barriers that restrict individuals from looking beyond their local allegiances and forces them to acknowledge their responsibilities to

* J.D. Candidate, 2012, Indiana University Maurer School of Law. I would like to thank Professor Alfred Aman, Jr. for his help in selecting the subject of this review and the Indiana Journal of Global Legal Studies Board of Editors for their assistance in the editing process.

1. Gillian Brock, Global Justice: A Cosmopolitan ACcount 4 (2009).

2. Brock's account of global justice is inspired by John Rawls' work, The Law of Peoples, in which he identifies what foreign policy principles representatives of liberal peoples would select if they were "subject to an appropriate veil of ignorance." Id. at 21. However, Brock's normative thought experiment diverges from The Law of Peoples in that, instead of using representatives, she randomly selects her delegates "for a range of reasons having to do with the problematic nature of representation." Id. at 76 n.17. Additionally, her set-up is different from the "typical Rawlsian story" with regard to the motivation of the parties involved in the global conference. Id. at $76 \mathrm{n} .16$. Unlike the representatives in Rawls' model, who are motivated by the interests of their people, in Brock's model "[ $t]$ he motivation of the parties in the original position is . . . a mix of selfinterest . . . and fairness." Id. While there are other aspects of Brock's model that differ from Rawls', they are beyond the scope of this review. For a more detailed discussion, see generally $i d$. at $17-83$.

3. Id. at 8.

Indiana Journal of Global Legal Studies Vol. 18 \#2 (Summer 2011)

(C) Indiana University Maurer School of Law 
the welfare of the global community. ${ }^{4}$ Brock's central assertion is that as members of the global community, we are responsible for ensuring that "all [people] are adequately positioned to enjoy the prospects for a decent life, such that they are enabled to meet their basic needs, their basic liberties are protected, and there are fair terms of cooperation in collective endeavours."5

Brock recognizes that this concept is susceptible to attack; therefore, her book is structured in response to her most severe skeptics. She identifies two skeptics worthy of addressing and responds to each of their arguments in different parts of her book. The first skeptic, the "nationalism skeptic," is notorious for "believ[ing] that cosmopolitanism interferes illegitimately with the defensible scope of nationalism and undermines . . . national self-determination."6 The second skeptic, "the feasibility skeptic," argues that Brock's cosmopolitan model of global justice is unlikely to succeed in practice. Brock responds to these skeptics' concerns by providing the reader with what she believes to be concrete and indisputable reasons why her theoretical framework of global justice is both realistic and feasible in practice. She sets the stage for this in part I of her book, where she defends her theoretical model of global justice through theory. In part II, she shifts her focus away from theory toward public policy. In this section, Brock responds indirectly to the feasibility skeptic's concerns by addressing ways in which the world can make progress toward accomplishing the goals of global justice. In part III, she returns to the theoretical issues, responds to both of the skeptics, and summarizes her argument.

In part I of her book, Brock addresses the theoretical framework of her model of cosmopolitan global justice. She borrows Rawls' "veil of ignorance" model and uses it to determine what individuals would agree to be the fairest framework to govern the world's inhabitants. ${ }^{7}$ Brock sets up her thought experiment by imagining a hypothetical global conference where randomly selected delegates attend and debate over the appropriate framework. ${ }^{8}$ The world in which this conference takes place is what Brock labels the "ideal world," which she claims to be as closely modeled after the real world as possible. ${ }^{9}$ She explains that the hypothetical delegates are blind to their situation in the world; they live

4. Id. at 9 .

5. Id. at 322 .

6. Id. at 4 .

7. Id. at $48-50$.

8. Id. at $48-49$.

9. Id. (organizing the world into various communities that reflect current political, religious, national, cultural, or linguistic divisions and the self-interested quality of individuals). 
"behind a veil of ignorance." 10 It is her belief that "if people do not know what positions they might find themselves in during the lottery of life, they will pay more attention to what would constitute fair arrangements." 11 She does this so that her delegates will be unable to predict with any amount of certainty where they could be positioned in the world as a means to avoid partiality. However, Brock does provide the delegates with some information that she deems indispensible for purposes of determining what would be the most just system for interactions and relations among members of the global community. The delegates know "the data about our urgent global collective problems," including the severe threats to security and peace, terrorist activities, drug cartels, environmental concerns, and health risks. ${ }^{12}$

According to Brock, these hypothetical delegates are more likely to honestly and seriously consider what they would be willing to tolerate in their world given that they do not know what their life situation will be. She claims that as a result, delegates would agree on a framework that ensures each person would, at a minimum, enjoy prospects for a decent life. She claims that this agreement would consist of two central claims-that all individuals would enjoy some basic freedoms and that all people would be protected from serious harm. ${ }^{13}$ She argues that the delegates would likely agree that a world government would be a less desirable form of governance and that some form of mixed governance among the states would be a more prudent choice for achieving these goals. ${ }^{14}$ Brock reiterates that, in the end, "whatever governing structures [the delegates] endorse would (at a minimum) have as the central part of their mandate to ensure that people are so positioned that meeting their basic needs is within their reach, and that their basic liberties are protected." 15 Brock acknowledges that this model, grounded in a needs-based minimum floor principle, is vulnerable to attack due to

10. Id. at 49 (explaining that they "do not know where they live, the territory's size, how numerous or powerful the people are, what level of economic development is dominant in that territory, [or] how well endowed it is with natural resources").

11. Id. at 48 .

12. Id. at 49 .

13. Id. at 50 .

14. See id. at 52-53. Brock explains that delegates might agree on a mixed form of governance that retains state authority over some matters (such as "people's abilities to meet their needs and protect their freedoms"), but also allows for joint sovereignty "where protection of vital interests can be secured only if there is widespread cooperation across states." Id. She discusses how delegates might find it prudent to choose this form of governance because of the significance of their decision. She offers the reader two reasons why this is so: (1) it would be a more risk-adverse and cautious approach; and (2) "there is a legitimate concern about what might transpire if world government turns out to be very bad." Id. at 53.

15. Id. at 53 . 
its merely theoretical basis ${ }^{16}$ (especially from those cosmopolitans who might select a model grounded in a "difference principle"); ${ }^{17}$ however, to rebut, she provides the reader with some convincing findings from experimental psychology to support her position. ${ }^{18}$

At the end of part I, Brock tackles some of the concerns held by the nationalism skeptic by addressing whether genuine international democracy can be achieved.19 She discusses what "global governance" structure would be most effective for realizing the goals of her global justice model. Brock begins by listing nine reasons why global governance is necessary in order to pursue global justice in an evenhanded manner. ${ }^{20}$ It is important to note that Brock's definition of global governance is not meant to be synonymous with the term "world governance." In Brock's mind "'global governance' refers to how we manage interests affecting residents of more than one state in the absence of a world government (or centralized power ... .)."21 According to Brock, the most effective form of global governance is a system based on accountability and effectiveness. ${ }^{22}$ She claims that a "responsive form of democracy" is best because it will be better able to respond to people's interests and more successful at securing those interests. ${ }^{23}$

While up to this point Brock has focused primarily on ideal theory, in part II, Brock shifts the reader's attention to the practical ways her model can be realized. She turns her focus away from theory and moves to issues of public policy in an attempt to show the reader how the world can move closer toward realizing the goals of global justice. Brock's overall goal in part II is to combat the arguments made by her feasibility skeptic. She identifies a number of the skeptic's concerns regarding the practicality and workability of her model of global justice. She focuses on a number of public issues in the world that her model

16. Id. at 54 .

17. Id.; see also id. at 46-47 (discussing the work of Darrel Moellendorf, which supports the more traditional cosmopolitan proposition that representatives would choose a model based on a "global difference principle").

18. See id. at 54-56. Brock cites a study by psychologists Norman Frohlich and Joe Oppenheimer that suggests that "ordinary folk" would agree on some form of just distribution. Their study indicated that in order to balance the needs, incentives, and entitlements of individuals in a society, "the most just distribution of income [would be] that which maximizes the average income only after a certain specified minimum income is guaranteed to everyone." Id. at 55 (quoting NORMAN FROHLICH \& JOE A. OPPENHEIMER, CHOOSING JUSTICE: AN EXPERIMENTAL APPROACH TO ETHICAL THEORY 201 (1992)).

19. Id. at $84-85$.

20. Id. at 86-89 (providing examples such as, international economic interdependence, global health problems, and uneven distribution of natural resources).

21. Id. at 84 .

22. Id. at 104 .

23. Id. at 105-09. 
can reform, such as global poverty, taxation reform, humanitarian intervention, immigration, protecting basic liberties, as well as problems involved with the global economy. ${ }^{24}$ Brock pays significant attention to each of these issues in her book as a means of defending her model against the feasibility skeptic, but for the sake of brevity, I will focus on her use of two issues-global poverty and taxation.

At the beginning of the section on global poverty, Brock presents the reader with compelling figures concerning the levels of poverty in the world today. ${ }^{25}$ It is Brock's position that impoverished countries remain impoverished in part due to the inferior quality of institutions in those countries. In essence, she argues that the governing bodies and organizations in these nations cannot "manage conflict, maintain law and order, enable society and political stability, and sustain its regulatory capacity." 26 Brock claims that reforming international institutions can have a dramatic effect on the quality of institutions in these developing countries. ${ }^{27}$ In this chapter, Brock concentrates on how reforming the current practices that regulate world taxation can impact global poverty. Her suggested reforms focus on restructuring our current system of international taxation, specifically in a way that makes transactions more transparent and participants more accountable, which Brock believes will cause global poverty to diminish. Brock provides the reader with a detailed look at some of the problems developing countries face because large corporations are "effectively escaping taxation" in these countries. ${ }^{28}$

Brock claims that financial structures such as tax havens and transfer pricing, coupled with the lack of requirements for trade transparency and corporate accountability on an international level, offer large corporations the opportunity to evade taxes. As a result of these practices, developing nations lose revenue. This lost revenue could provide the funds needed to create higher quality domestic institutions that would provide citizens more opportunities for fulfilling their basic

24. Id. at 117.

25. Id. at 120. Approximately " 25 per cent of the world's population subsists below the international poverty line. ... [A] sample of what we know about how well people are currently able to meet their basic needs [includes]: 1.1 billion do not have access to safe drinking water, 2.6 billion do not have basic sanitation, and 1 billion lack adequate shelter. At least 850 million suffer from malnutrition and its effects. Diseases transmitted through water or human waste are the second leading cause of death among children worldwide, with 3,900 children dying every day from such diseases. An estimated 800 million adults are illiterate. Approximately 115 million children do not get the most basic forms of education." Id.

26. Id. at 121 .

27. Id.

28. Id. at 125 . 
needs. ${ }^{29}$ Brock argues that the international trade industry needs more regulation so that large corporations and wealthy individuals cannot take advantage of people in these underdeveloped and politically corrupt countries. In essence, the international community should eliminate "tax havens, tax evasion, and transfer pricing schemes that do not reflect 'arm's-length' pricing" in order to hold corporations accountable for their practices and support democracy. ${ }^{30}$

Brock also supports the view that corporations should pay an additional public goods tax. ${ }^{31}$ She contends that certain global public goods, such as peace, social and political stability, and effective law enforcement, facilitate trade, and because of this, those who participate in global trade should pay for their enjoyment. ${ }^{32}$ She also argues for a number of other global tax schemes, such as a carbon tax, a currency tax, an e-mail tax, a tax on world trade, a tax on the international arms trade, and aviation fuel taxes as means to aid developing nations. ${ }^{33}$

Of course, the next issue is how the global community would coordinate, collect, and disperse the revenue raised by these tax schemes in a way that would further the goals of global justice. Brock envisions that nation-states would make agreements to formulate an "internationally harmonized tax regime," and each nation would be responsible for implementing specific global taxes through its regular tax authority. ${ }^{34}$ "Each nation would [then] pass on an agreed amount or percentage to an international organization for spending in line with the specified global objectives." 35 In effect, a new international organization would need to be created to oversee this "global justice fund." 36 Brock argues that this is a feasible solution for combating global poverty and that it does not require universal acceptance to be successful. ${ }^{37}$

Throughout the rest of part II, Brock explores the other areas of the global community that require public policy reform, focusing on how reform in those areas can achieve the goals of her global justice model. Brock's reforms often require the formation of a new international organization or serious modifications to existing international organizations. ${ }^{38}$ However, current international bodies, such as the

29. Id. at 127 .

30. Id. at 139 .

31. Id. at 130.

32. Id.

33. Id at 132-35.

34. Id. at 136 .

35. Id.

36. Id.

37. Id.

38. See, e.g., id. at 177 (Brock creates an international organization called the "Vital Interests Protection Organization" that has the power to "authorize the use of force to 
United Nations and the United Nations Security Council, are underfunded and function poorly as a means to protect all members of the global community. ${ }^{39}$ It may be infeasible to create new international organizations that will successfully combat issues such as global poverty, tax evasion, and humanitarian intervention. This concern is. not directly addressed in the book, but in part III, similar feasibility skeptic arguments are contested.

In part III, Brock returns to her ideal theory and attempts to dismantle the concerns of both of her skeptics. First, Brock addresses the nationalism skeptic's concern that her model interferes with national allegiance. She refutes this by explaining that her normative model provides "adequate space for legitimate forms of nationalism or patriotism." 40 Brock accepts that many people have strong attachments to their nations and "that these attachments can provide . . . significant meaning in their lives." 41 She explains that her main goal is to determine what limits can be placed on these attachments so as to prevent partiality from impeding the realization of the goals of her model. She contends that her model allows more space for legitimate national aspirations, but that as members of the global community, we owe all other members certain obligations first. Specifically, she asserts that there are "morally salient connections between ' $u$ s' in the developed world and 'them' in the developing world" and, as a result, we owe these developing nations certain obligations. ${ }^{42}$ Due to a number of global practices that implicate "us" in perpetuating the cycle of global poverty in these developing nations, "we" owe "them." 43 For example, she highlights how individuals in developing nations do not have adequate health care resources due to the current international health care worker recruitment practices of developed nations. ${ }^{44}$

By participating in activities that perpetuate the cycle of global poverty, we are not ensuring that all people are adequately positioned to enjoy the prospect of a decent life. As a result, these developed nations owe certain external obligations to the global community. Those

restore or ensure that relevant vital interests are adequately protected" in all nations. This new organization would also be resourced through taxes.); id. at 202 (arguing for the creation of an international agency to oversee the fair recruitment of health care workers from developing nations by developed nations).

39. Id. at 185 .

40. Id. at 274 .

41. Id.

42. Id. at 289 .

43. Id.

44. Id. at 285 (addressing the devastating impact "brain drain" has on developing nations when the majority of a nation's skilled citizens emigrate, leaving behind the less skilled citizens). 
external obligations include ensuring that the appropriate international institutions have been created and that those institutions are making considerable progress toward ensuring that everyone's interests are adequately protected in the world. Only after a nation has satisfied its external obligations can it then "prioritize meeting the needs of [its] compatriots." 45 Here is where Brock claims that her model provides room for legitimate national allegiance. She summarizes her argument by stating that "[s]o long as individuals within the nation are adequately respected and positioned to enjoy decent lives, and provided that nations play their part in the collective project of ensuring a globally just world, there is discretionary space for nations to pursue national aspirations." 46

At the end of part III, Brock addresses a number of concerns held by the feasibility skeptic. Brock consolidates those concerns into four main questions. ${ }^{47}$ She addresses the first three-(1) the goals of global justice, (2) how to make progress toward those goals, and (3) how to track that progress-by arguing that the goals of global justice can be realized through institutional reforms and the creation of new international organizations that will oversee and track its development. ${ }^{48}$ In response to the fourth question, which centers on how the global community will be motivated to pursue the goals of global justice, Brock claims that all nations have an interest in creating a global structure centered on accountability that prevents corruption and abuse so as to ensure that our "collective security can flourish." 49 This interest will motivate nations to support and become involved in institutional reforms that will achieve the goals of global justice. ${ }^{50}$ Brock argues that some goals can be achieved through reform of currently existing international bodies, but this requires that large groups of people demand more legitimacy from those institutions. ${ }^{51}$ Her method for motivating people to demand reform includes altering school curricula in a manner that heightens awareness of global problems and encouraging the formation of a "world citizen" identity. ${ }^{52}$

45. Id. at 290 .

46. Id. at 324 .

47. Id. at 326 (summarizing the feasibility skeptic's concerns as "(A) Goals: What are the goals of global justice?; (B) Transition: How can we make progress towards these?; (C) Measurement: How can we track progress?; [and] (D) Motivation: How will we create the motivation to pursue global justice or otherwise deal with the issue of global authority (or lack thereof)?" (internal citations omitted)).

48. Id. at $326-29$.

49. Id. at 329 .

50. Id.

51. Id. at 332 .

52. Id. 
Brock hoped to offer the reader "a vision of a realistic utopia . . . namely, as a normative account of what we can reasonably hope for in justice at the global level, which takes people as they are now, is workable and applicable to ongoing social and political arrangements, and ... could be realized in the near future." 53 While her model for global justice is compelling and well developed, there remain a number of practical issues that need to be resolved. She addresses a number of notable concerns held by her skeptics, but there are several important questions left unanswered, for example: (1) Who will initiate and design the necessary curriculum for the required educational reform?; (2) Who will provide the resources and training for teachers?; (3) Who will provide the initial startup capital to fund these global institutions that are meant to oversee and promote global justice?; (4) Who will initiate their formation?; (5) From where will these institutions operate?; and (6) How exactly will they garner their authority? In other words, while Brock provides the reader with more concrete suggestions for implementing her cosmopolitan model of global justice, her theory is still rather more ideal than practical reality. These unresolved issues make her model appear less realistic and more utopian.

53. Id. at 40 . 
